\title{
Factors Influencing Entrepreneurs' Business Performance in Small and Medium Businesses: Comparative Analysis Between Demographic and Environmental Factors in Bangladesh
}

\author{
SERENA AKTAR ${ }^{*}$
}

\begin{abstract}
Performance is viewed as the implementation of an action or one's ability. Good performance is also related with achieving greater market share earning more profit. The main aim of this study is to examine and compare the factors influencing entrepreneurs' businesses performance. It is a comparative analysis between the demographic and environment related factors. The present article is a survey-based research. A total number of 400 questionnaires were distributed among some small and medium entrepreneurs. Data on their performance, aspects related to (the respondents') demographic and environment were collected. The data have been analyzed by using SPSS software. A model has been developed in order to show and test the relationship among demographic factors and environment related factors and the entrepreneurs' business performance in this study. The results revealed that individually (among entrepreneurs) there is a positive and strong significant influence of position in birth order, number of employees(demographic factors); sources of loan collection and family support(environment-related factors) on entrepreneurs' business performance.
\end{abstract}

Key Words: Entrepreneurs, Demographic factors, Environment factors, Business Performance.

\footnotetext{
*Assistant Professor of Management, Faculty of Business, Northern University Bangladesh, Dhaka. E-mail: serene7868@gmail.com
} 


\section{INTRODUCTION}

In the current global economy, SMEs (Small and Medium Enterprises) are gradually being regarded as influential tools for economic development and their business performance (Islam, Khan, Obaidullah and Alam, 2011). Business performance has been interpreted in several ways from different dimensions (Foley and Green, 1989). Performance is a function of ability, motivation and opportunity of entrepreneurs (Chandler and Hanks, 1994). The ability to identify business opportunity (entrepreneurial competence) and gathering of resources (managerial competence) are directly related to performance. Duh (2003) finds firm characteristics along with entrepreneur's personal characteristics work as the preliminary determinants of their performance. Small and medium enterprises (SMEs) are fundamental for economic growth and development than the larger industries (Kongolo, 2010). Small and medium enterprises (SMEs) are presently considered to be the major source of vigor, modernization and flexibility in budding and developing countries. SMEs contribute substantially to economic development and employment generation (Koh et al., 2007). Small and medium enterprises (SMEs) work as a potential economic back bone and make huge contributions to employment than large businesses in any country (Chin et al. 2012).

The paper begins with a review of some factors which are related to entrepreneurs' business performance. Afterwards, the study describes methodology and then analysis and discussion of the results in order to conclude with general remarks and some guidelines related to the development of entrepreneurs' business performance.

\section{LITERATURE REVIEW}

Elvis Munyaradzi Ganyaupfu (2013) finds that managerial competence, educational qualifications, work experience, location, size of the firm, period the enterprise has operated-all have statistically significant positive effects on the success of SMEs. The main factors associated with SMEs growth are SME's operational capital, number of owners, staff-size, rate of profit, annual level of products, access to basic market information, linkage to supportive bodies, business improvement services, distances to input-sources and marketplaces, and manager-owner's age as well as experience in business activities (Hussein Mashimba and Rainer Kühl, 2014). There is a relationship between entrepreneurship knowledge and the performance of small-scale businesses (Msoka Elizabeth M., 2013). 
Mastura Jaafar et al., (2010) recommend the secondary and upper levels of formal education and prior experience of entrepreneurs are not related to their business performance. They also mention that selfconfidence and highly independent personalities could have stimulated their business interest and aided their survival in the industry. The growth of SMEs is influenced by several interrelated factors, which include business environmental factors that are beyond the SMEs' control and internal factors of the SMEs. The external factors include the legal and regulatory framework, access to external financing, and human resources capacities. The internal factors comprise entrepreneurial characteristics, management capacities, marketing skills, and technological capacities (Asma Benzazoua Bouazza et al., (2014) showed the positive and significant impact factors of investment, entrepreneurial experience, business profile and culture. Stella Kemunto Osinde et al., (2013),find that business development or performance states an improvement in the growth of sales and growth in market shares on the various businesses they were operating. Muhammad Qureshi Hariset al.,(2012), show that female owned businesses are less successful than male owned businesses because females possess less such personal characteristics which are critical for success in business. The growth of SMEs depends on market access, government policy and credit access. The study establishes that some of the entrepreneurs who had started SMEs had no training in business. So, government should organize conferences and seminars to train entrepreneurs on business planning; book keeping; marketing; financial management and customer relations. A good number of SME owners did not have access to credit (Huka Sharuand and Dr. Wario Guyo, 2015). Mohammed Alkali (2012) finds that capital access and government support were finds to be significantly related to business performance of the enterprises.

\section{OBJECTIVES}

The main objective of this study is to identify the factors which are most important for entrepreneurs' business performance in Bangladesh. The following are the specific objectives of this study:

i. to identify the factors which determine entrepreneurs' business performance; 
ii. to examine the relationship between demographic and environment related factors and entrepreneurs' business performance.

iii. to construct a model exploring the relationship between demographic and environment related factors and entrepreneurs' business performance; and

iv. to suggest ways how entrepreneurs can enhance their performance.

\section{METHODOLOGY}

This research is mainly based on primary data collected with a structured questionnaire designed on the basis of objectives and hypotheses. Likert- fivepoint scales have been used to design questionnaire where the value 1 is assigned to the answer of 'utmost important'; 2 is assigned to the answer of 'very important'; 3 is assigned to the answer of 'moderate important'; 4 is assigned to the answer of 'less important' and 5 is assigned to the answer of 'no important' answer for each question. The questionnaire is divided into three parts. Demographic factors (such as age, gender, educational ability, marital status and work experience) of the respondents are the first part, environment related factors are the second part and entrepreneurs' business performance (such as market share and profit growth) is placed as part three. A total of 400 entrepreneurs have been surveyed using simple random sampling method. Data are collected from the different urban areas in Bangladesh. The secondary data have been collected from different articles and books. For analysis, the statistical package SPSS version $20(\mathrm{IBM})$ has been used. The following statistical techniques are applied to analyze the data:

1. Reliability analysis

2. Descriptive statistics (Mean and Standard deviation)

3. Multiple regression analysis

4. Hypothesis Testing

Sampling Technique: A total of 400 respondents have been selected by using simple random sampling technique from Bangladesh. Types of businesses are food stores, clothing stores, book stores, drugstores, hotels, beauty shops, electronics and hardware etc. Existing definition of SME is recommended by Better Business Forum and accepted the standard by Ministry of Industry (MOI, Bangladesh) and Bangladesh Bank. Criteria of the definition of SME are given below: 
Definition of Small and Medium Enterprise: Small Enterprise and Medium Enterprise refers to the firm/business, which is not a public limited company and complies the following criteria:

\begin{tabular}{|c|c|c|c|c|c|}
\hline \multirow{2}{*}{$\begin{array}{l}\text { Serial } \\
\text { No. }\end{array}$} & \multirow[t]{2}{*}{ Sector } & \multicolumn{2}{|c|}{ Small Enterprise } & \multicolumn{2}{|c|}{ Medium Enterprise } \\
\hline & & $\begin{array}{l}\text { Fixed Asset } \\
\text { other than } \\
\text { Land and } \\
\text { Building (Tk.) }\end{array}$ & $\begin{array}{l}\text { Employed } \\
\text { Manpower } \\
\text { (not above) }\end{array}$ & $\begin{array}{l}\text { Fixed Asset } \\
\text { other than Land } \\
\text { and Building } \\
\text { (Tk.) }\end{array}$ & $\begin{array}{c}\text { Employed } \\
\text { Manpower } \\
\text { (not } \\
\text { above) }\end{array}$ \\
\hline 1. & Service & $\begin{array}{c}50,000- \\
50,00,000\end{array}$ & 25 & $\begin{array}{c}50,00,000- \\
10,00,00,000\end{array}$ & 50 \\
\hline 2. & Business & $\begin{array}{c}50,000- \\
50,00,000\end{array}$ & 25 & $\begin{array}{c}50,00,000- \\
10,00,00,000\end{array}$ & 50 \\
\hline 3. & Industrial & $\begin{array}{c}50,000- \\
1,50,00,000\end{array}$ & 50 & $\begin{array}{l}1,50,00,000- \\
20,00,00,000\end{array}$ & 150 \\
\hline
\end{tabular}

Source: https://wifibd.wordpress.com/2014/01/31/sme/ accessed on 26/10/15, 10:55pm

\section{Statement of the Hypotheses}

$H_{1:}$ There exists positive relationship between demographic factors and entrepreneurs' business performance.

$\mathrm{H}_{2}$ : There exists positive relationship between business environment related factors and entrepreneurs' business performance.

\section{Theoretical Framework of the Study}

The study proposes the following interface between business performances on the one hand, and demographic factors and environment-related factors, on the other. See the diagram below: 
Figure 1: Factors Influencing Entrepreneurs' Business Performance

\begin{tabular}{|c|}
\hline 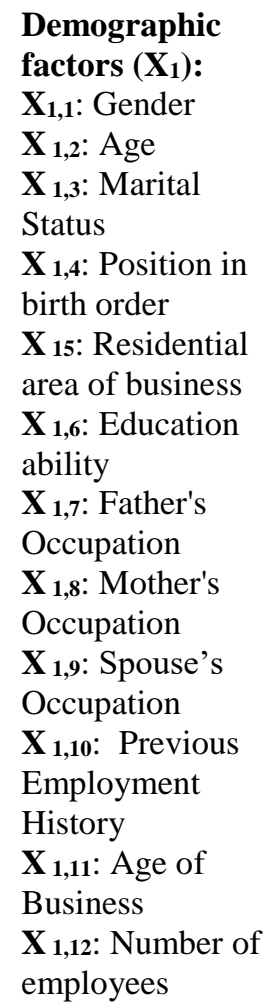 \\
\hline
\end{tabular}

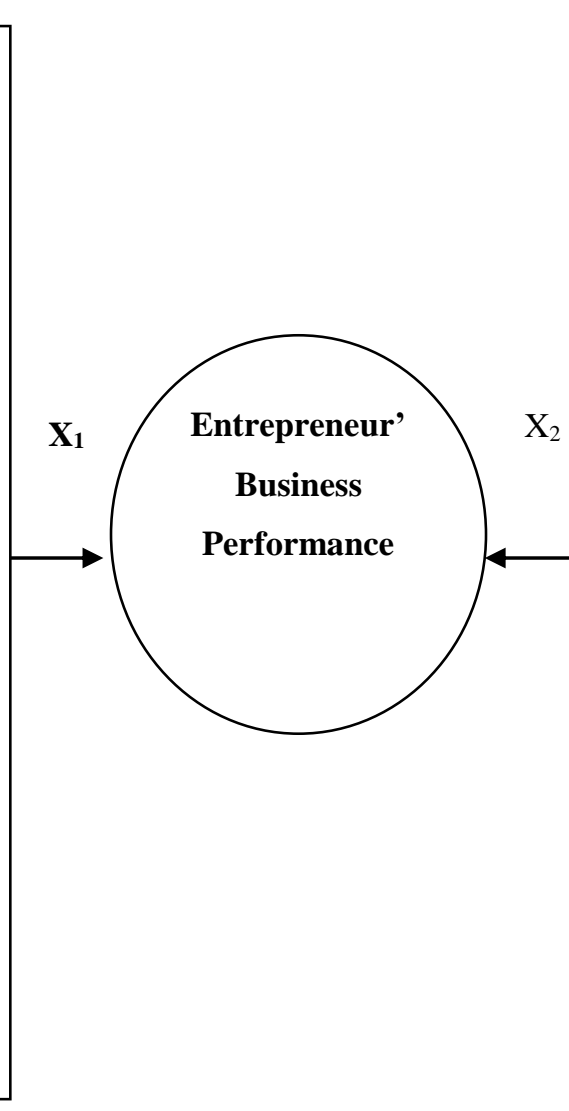

\section{Business \\ Environment \\ RelatedFactors}

$\left(\mathbf{X}_{2}\right)$ :

$\mathbf{X}_{2,1}$ : Sources of

Fund Collection

$\mathbf{X}_{2,2}$ : Sources of

Loan Collection

$\mathbf{X}_{2,3}$ : Investment

opportunity

$\mathbf{X}_{2,4}$ :Easy marketing

opportunity

$\mathbf{X}_{2,5}$ : Low legal

formalities

$\mathbf{X}_{2,6}$ : Established

national business

policy

$\mathbf{X}_{2,7}$ : Tax facility

$\mathbf{X}_{2,8}$ : Availability of

investors

$\mathbf{X}_{\text {2,9: } \text { : Secure }}$

Business

environment

$\mathbf{X}_{2,10}$ : Available

customer

$\mathbf{X}_{2,11}$ : Available information and communication

$\mathbf{X}_{2, \mathbf{1 2} \text { : Family }}$

background

$\mathbf{X}_{2,13}$ : Personal

experience

$\mathbf{X}_{2, \mathbf{1 4}}$ : Family

support

$\mathbf{X}_{2,15}$ : Government support

H216: Proper use of

human resources 


\section{ANALYSIS AND INTERPRETATION}

1. Reliability Analysis: Reliability is the overall consistency of a measure. One of the most popular reliability statistics in use today is Cronbach's alpha (Cronbach, 1951).Cronbach's (alpha) is used as an estimate of the reliability.Nunnaly (1978) indicated 0.70 to be an acceptable reliability coefficient. Annex Table1 shows the value of the Cronbach's Alpha. Cronbach's alphais the instrument of checking internal reliability. The results of Cronbach alpha are 0.518 (demographic factors); 0.671(environment related factors) and 0.711 (all variables). The value of Cronbach's Alpha of all variables is higher than the standard value (0.70) presented by Nunnally (1978). Therefore, it is found that the instruments used in this study have strong internal reliability and it could be used with confidence for the application of further statistical analysis and interpretation.

\section{Descriptive Statistics (Mean and Standard deviation):}

The descriptive data show that out of 400 respondents; most of them (98\%) are male and rest of them (2\%) are female. The mean score for respondents' gender is 1.02 (standard deviation is 0.007). Table 2 (Appendix) also presents the age distribution of the respondents. Among 400 respondents; 163 respondents' age range are in between 26years to 35years, next highest 149 employees are in the range of 36years to 45years, 46respondents' age range are in between $15 y$ ears to 25 years and only 42 respondents age range are the above of 46 years. So majority of the respondents are belonging into the young adult (15 years to 35 years) age group. The mean score for respondents' age is 2.47 (standard deviation is 0.042 ).

Table 2 (Appendix) visibly presents the educational level of the respondents. Among 400 respondents; 47 respondents' education are in below of SSC, 91 respondents are passed SSC, 135 respondents are passed HSC, and 105 and 18 respondents are graduateand post graduate respectively. The mean score for respondents' educational qualification is 2.92 (standard deviation is 0.055 ). Table shows that most of the respondents (309) are married and rest (91) are single. The mean score for respondents' marital status is 1.77 (standard deviation is 0.021 ).

Among 400 respondents; a total number of 115 respondents are having 4 years to 5 years experiences, 96 respondents having 5-10 years experiencce, 2-3 yearsexperience having by 94respondents, 35 respondents are having 11 years to 15 years business experience and 29respondents have20years or more business experience. The mean score for respondents' business experience is 3.53 (standard deviation is 0.075).The annex table -II shows that out of 367 respondents are living in urban area, 122 respondents' father are not having any 
jobs, 175 respondents mother are not having any job, a number of 171 respondents' are $2^{\text {nd }}$ born baby of their parents. Lastly 5 to 15 numbers of employees are working under 248 respondents.

\section{Multiple Linear Regression Analysis}

\section{Multiple Linear Regression Analysis}

The prediction of $\mathrm{Y}$ is modelled by the following equation:

$\mathrm{Y}^{\prime}{ }_{\mathrm{i}}=\mathrm{b}_{0}+\mathrm{b}_{1} \mathrm{X}_{1 \mathrm{i}}+\mathrm{b}_{2} \mathrm{X}_{2 \mathrm{i}}+\ldots+\mathrm{b}_{\mathrm{k}} \mathrm{X}_{\mathrm{ki}}$

Where

$\mathrm{X}_{1 \mathrm{i} \ldots \ldots \ldots \ldots . . . . . .} \mathrm{X}_{1 \mathrm{n}}=$ Independent demographic variables

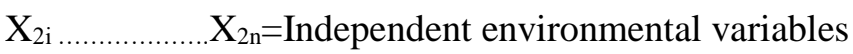

TABLE 1

MODEL SUMMARY

\begin{tabular}{|c|c|c|c|c|c|c|c|c|c|}
\hline \multirow[t]{2}{*}{ Model } & \multirow[t]{2}{*}{$\mathrm{R}$} & \multirow[t]{2}{*}{ R Square } & \multirow{2}{*}{$\begin{array}{l}\text { Adjusted R } \\
\text { Square }\end{array}$} & \multirow{2}{*}{$\begin{array}{l}\text { Std. Error of } \\
\text { the Estimate }\end{array}$} & \multicolumn{5}{|c|}{ Change Statistics } \\
\hline & & & & & $\begin{array}{l}\text { R Square } \\
\text { Change }\end{array}$ & F Change & df1 & df 2 & Sig. F Change \\
\hline 1 &.$\underset{\mathrm{a}}{.401}$ & .161 & .131 & .895 & .161 & 5.278 & 14 & 385 & .000 \\
\hline 2 & .571 & .326 & .300 & .803 & .326 & 12.390 & 15 & 384 & .000 \\
\hline
\end{tabular}

a. Predictors: Demographic factors

b. Predictors: Environmental factors

The above model-1 indicates that the unadjusted multiple $\mathrm{R}$ for this data is 0.161 , but that the adjusted multiple $\mathrm{R}$ is 0.131 . This rather large change is due to the fact that a relatively small number of observations are being predicted with a relatively large number of variables. The unadjusted value of $\mathrm{R}^{2}$ means that all subsets of predictor variables will have a value of multiple $\mathrm{R}$ that is greater than 0.131 . Note also that these variables in combination significantly (Sig. F Change $=0.000$ and 0.000 ) predict the business performance by demographic factors and environmental factors. The large change in $\mathrm{R}^{2}$ is from model 1 to model 2 , with an $\mathrm{R}^{2}$ change of .165 from .161 to .326. 
TABLE 2

Coefficients of Multiple Regression Models

\begin{tabular}{|c|c|c|c|c|c|c|}
\hline \multirow{2}{*}{\multicolumn{2}{|c|}{ Model (1) }} & \multicolumn{2}{|c|}{$\begin{array}{l}\text { Unstandardized } \\
\text { Coefficients } \\
(2)\end{array}$} & \multirow{2}{*}{$\begin{array}{c}\text { Standardized } \\
\text { Coefficients (3) } \\
\text { Beta }\end{array}$} & \multirow[t]{2}{*}{$\begin{array}{l}\text { (4) } \\
\mathrm{t}\end{array}$} & \multirow[t]{2}{*}{$\begin{array}{l}\text { Significa } \\
\text { nce level }\end{array}$} \\
\hline & & $\begin{array}{l}\text { (A) } \\
\mathrm{B}\end{array}$ & $\begin{array}{l}\text { (B)Std. } \\
\text { Error }\end{array}$ & & & \\
\hline \multirow[t]{15}{*}{1} & (Constant) & 4.184 & .484 & & 8.652 & .000 \\
\hline & Gender & -.739 & .332 & -.108 & -2.225 & .027 \\
\hline & Age & -.162 & .080 & -.140 & -2.032 & .043 \\
\hline & Marital Status & .361 & .135 & .158 & 2.665 & .008 \\
\hline & Number of Children & -.056 & .042 & -.083 & -1.325 & .186 \\
\hline & Number of brothers and sisters & -.083 & .031 & -.139 & -2.664 & .008 \\
\hline & Position in birth order & .086 & .036 & .118 & 2.390 & .017 \\
\hline & Residential area of business & -.090 & .167 & -.027 & -.539 & .590 \\
\hline & Education & -.023 & .043 & -.026 & -.520 & .603 \\
\hline & Father's Occupation & .021 & .030 & .034 & .686 & .493 \\
\hline & Mother's Occupation & .064 & .027 & .125 & 2.381 & .018 \\
\hline & Spouse's Occupation & .000 & .029 & -.001 & -.025 & .980 \\
\hline & Previous Employment History & .083 & .045 & .089 & 1.823 & .069 \\
\hline & Age of Business & -.140 & .038 & -.218 & -3.698 & .000 \\
\hline & Number of employees & .168 & .044 & .193 & 3.828 & .000 \\
\hline \multirow[t]{16}{*}{2} & (Constant) & .423 & .326 & & 1.299 & .195 \\
\hline & Sources of Fund Collection & .131 & .039 & .148 & 3.362 & .001 \\
\hline & Sources of Loan Collection & -.011 & .032 & -.016 & -.357 & .721 \\
\hline & Investment opportunity & .199 & .040 & .230 & 5.016 & .000 \\
\hline & Easy marketing opportunity & -.087 & .040 & -.099 & -2.154 & .032 \\
\hline & Low legal formalities & .035 & .037 & .047 & .952 & .342 \\
\hline & Established national business policy & .082 & .038 & .117 & 2.179 & .030 \\
\hline & Tax facility & -.120 & .039 & -.183 & -3.047 & .002 \\
\hline & Availability of investors & .140 & .037 & .197 & 3.739 & .000 \\
\hline & Secure Business environment & .176 & .045 & .186 & 3.915 & .000 \\
\hline & Available customer & .220 & .049 & .209 & 4.545 & .000 \\
\hline & $\begin{array}{l}\text { Available information and } \\
\text { communication }\end{array}$ & .072 & .039 & .082 & 1.853 & .065 \\
\hline & Family background & -.095 & .031 & -.136 & -3.105 & .002 \\
\hline & Personal experience & -.006 & .040 & -.007 & -.146 & .884 \\
\hline & Family support & .049 & .036 & .066 & 1.361 & .174 \\
\hline & Government support & .060 & .036 & .084 & 1.686 & .093 \\
\hline
\end{tabular}


The column (5) of Table 2 presents the level of significance of each variable. Most of the demographic variables are strongly significant in the above table. The significance level value of some demographic factors such as number of children (0.186), residential area of business (0.590), education (0.603), father's occupation (0.493), spouse's occupation (0.980) and previous employment history (0.069) are greater than 0.05 which imply that these factors have no significant impact on increasing entrepreneurs' business performance. The correlation between marital status $(B=0.361, t=2.665)$ and entrepreneurs' business performance; Number of employees $(\mathrm{B}=0.168, \mathrm{t}=3.828)$ and entrepreneurs' business performance are relatively high and positive than all others demographic factors.

From the above table, model-2 manifests that the column (5) of Table 2 value of some environment related factors such as Sources of Loan Collection (0.721), Low legal formalities (0.342), Available information and communication (0.065), Personal experience (0.884), Family support (0.093) are greater than 0.05 which imply that these factors have no significant impact on increasing entrepreneurs' business performance. The correlation between Investment opportunity $(B=0.199, t=5.016)$ and entrepreneurs' business performance; Secure Business environment $(\mathrm{B}=0.176, \mathrm{t}=3.915)$ and entrepreneurs' business performance; Available customer $(\mathrm{B}=0.220, \mathrm{t}=4.545)$ and entrepreneurs' business performance are relatively high and positive than all others environment related factors.

\section{DISCUSSION AND CONCLUSIONS}

The study results indicate that both set of factors (i.e. demographic and environmental) have positive and significant impact on entrepreneurs' business performance in Bangladesh. In this study, fourteen demographic factors and sixteen environment related factors were hypothesized to have influence on the entrepreneurs' business performance. The demographic factors (such as age, position in birth order, spouse's occupation, previous employment history, age of business and number of employees) have strong positive influence on entrepreneurs' business performance in SME sectors but all demographic factors are not equally influential factors to increase entrepreneurs' business performance. From the one-way ANOVA test, it is also stated that there exists positive relationship between environment related factors ( (such as sources of fund collection, sources of loan collection, investment opportunity, easy marketing opportunity, low legal formalities, established national business policy, tax facility, available investors are ready to invest, secure business environment, available information and communication, personal experience, 
family support and government support) and entrepreneurs' business performance in SME sectors.

The results confirm that human resources management practices utilized in the SMEs are a significant factor determining performance of the business. The current study offers a guideline to the entrepreneur of small and medium enterprises about how they will increase their business performance. They should not emphasize only on demographic factors or environmental factors individually. So, they should place high emphasis on these two factors to retain and increase their effectiveness and efficiency of business.

\section{REFERENCES}

Adnan, Z., Abdullah, H.S. and Ahmad, J. (2011), Direct influence of human resource management practices on financial performance in Malaysian R\&D companies, World Review of Business Research, Vol. 1,No.1,pp 61-77.

Asma Benzazoua Bouazza, Diabate Ardjouman and Dr. Othman Abada (2015), Establishing the Factors Affecting the Growth of Small and Medium-sized Enterprises in Algeria, American International Journal of Social Science, Vol. 4, No. 2;pp-101-115.

Cacciolatti, L., Fearne, A. and McNeil, D. (2011), Empirical evidence for a relationship between business performance and the use of structured marketing information amongst food and drink SMEs, Academy of Marketing Conference (5-7 July 2011), University of Kent: United Kingdom.

Chandler, G. and Hanks, S. (1994). Market attractiveness, resource-based capabilities, Venture strategies and venture performance. Journal of Small Business Management, Vol.12, No.1, pp-27-35.

Charney, A. and Libecap, G. D. (2000), Impact of entrepreneurship education, Kauffman Center for Entrepreneurial Leadership.

Chin, T. A., Hamid, A. B. A., Rasli, A., and Baharun, R. (2012). Adoption of supply chain management in SMEs, Procedia-Social and Behavioral Sciences, Vol.65, pp- 614-619.

Cronbach, L. J. (1951), Coefficient alpha and the internal structure of tests, Psychometrika, 16(3), 297-334.

Duh, M. (2003), Family enterprises as an important factor of the economic development: the case of Slovenia, Journal of Enterprising Culture, Vol.11, No.2, pp.111-130. 
Elvis Munyaradzi Ganyaupfu (2013), Entrepreneur and Firm Characteristics Affecting Success of Small and Medium Enterprises(SMEs)in Gauteng Province, International journal of Innovative Research in Management, issue 2 volume 9,pp-1-8

Fairoz, F.M., Hirobumi, T. and Tanaka, Y. (2010), Entrepreneurial orientation and business performance of small and medium scale enterprises of Hambantota District Sri Lanka, Asian Social Science, Vol.6No.3,pp. 34-46.

Foley, P. and H. Green (eds.) (1989), Small business success, London: Chapman

Huka Sharuand Dr. Wario Guyo (2015), Factors Influencing Growth of Youth Owned Small and Medium Enterprises In Nairobi County, Kenya, Volume 4 Issue 4, pp-973-980

Indarti, N. and Langenberg, M. (2005), A study of factors affecting business success among SMEs," Empirical evidences from Indonesia.

Islam, M. A., Khan, M. A., Obaidullah, A. Z. M. \& Alam, M. S. (2011), Effect of entrepreneur and firm characteristics on the business success of small and medium enterprises (SMEs) in Bangladesh, International Journal of Business and Management, Vol.6, No.3,pp. 289-299.

Islam, M. Z. and Siengthai, S. (2010), Human resource management practices and firm performance improvement in Dhaka export processing zone, Research and Practice in Human Resource Management, Vol.18, No.1, pp 60-77.

Joseph Rotich, Dr. Peter Cheruiyot and Charles Yegon (2014), The Impact Of SocioEconomic Factors On The Performance Of Small And Medium Size Enterprises: The Case Study Of Kericho County, Kenya,Globlal Journal Of Commerce And Management Perspective, Vol.3, No.4,pp 263-267

Keh, H. T., Nguyen, T. T .M. and Ng, H. P. (2007), The effects of entrepreneurial orientation and marketing information on the performance of SMEs, Journal of Business Venturing, Vol.22, pp 592- 611.

Koh, S. C. L, Demirbag, M., Bayraktar, E., Tatoglu, E., and Zaim, S. (2007), The impact of supply chain management practices on performance of SMEs, Industrial Management \& Data Systems, Vol107,No.1, pp103 - 124.

Kongolo, M. (2010), Job creation versus job shedding and the role of SMEs in economic development, African Journal of Business Management, Vol.4,No.11,pp 22882295.

Kristiansen, S., Furuholt, B. and Wahid, F. (2003), Internet cafe entrepreneurs: pioneers in information dissemination in Indonesia, The International Journal of Entrepreneurship and Innovation, Vol.4, No.4, pp 251-263. 
Mahmoud, M. A. (2011), "Market orientation and business performance among SMEs in Ghana," International Business Research, Vol.4, No.1, pp 241-251.

MasturaJaafar, SitiAishahMaideen and SitiZalehaMohdSukarno (2010), Entrepreneurial Characteristics of Small and Medium Hotel Owner-Managers, World Applied Sciences Journal, Vol.10 (Special Issue of Tourism \& Hospitality),pp 54-62.

Mohammed Alkali (2012),Assessing The Influence Of External Environmental Factors, on The Performance of Small Business Manufacturing Enterprises In Bauchi State, Nigeria, Interdisciplinary Journal of Contemporary Research In Business, Vol 4, No 7,Pp-621-628.

Msoka Elizabeth M.(2013), Do Entrepreneurship Skills Have an Influence on the Performance of Women Owned Enterprises in Africa? Case of Micro and Small Enterprises in Dar es Salaam, Tanzania, International Journal of Business, Humanities and Technology, Vol. 3 No. 3, pp-1-10.

Muhammad Haris Qureshi , Samia Ayyub , Prof. Dr. Muhammad Ramzan, Qamar Zaman and Muhammad Yasir (2012), Factors Affecting Small-Business Performance In Punjab-Pakistan: A Gender Based Analysis, Interdisciplinary Journal Of Contemporary Research In Business, Vol 4, No 2,pp-687-697.

Nunnally, J. C. (1978), Psychometric theory, (2nd ed.). New York: McGraw-Hill.

Semistatus Hussein Mashimba and Rainer Kühl ( 2014), Performance of Micro and Small-Scale Enterprises (MSEs) in Tanzania: Growth Hazards of Fruit and Vegetables Processing Vendors, Journal of Applied Economics and Business Research, Vol.4, No.2, pp 120-133.

Sinha, T. N. (1996), Human factors in entrepreneurship effectiveness, The Journal of Entrepreneurship, Vol.5, No.1,pp 23-39.

Stella Kemunto Osinde, Dr Mike Iravo, Dr Charles Munene and Debora Omayio (2013),Effect of Business Development Services on the Performance of Small Scale Enterpreneurs in Kenya. A Survey of Small Scale Enterprises In Kenya, Interdisciplinary Journal Of Contemporary Research In Business, Vol 5, No 1,pp-292-300.

Swierczek, F. W. and Ha, T. T. (2003), Entrepreneurial orientation, uncertainty avoidance and firm performance: An analysis of Thai and Vietnamese SMEs, International Journal of Entrepreneurship and Innovation, Vol.4, No.1, pp 4658. 


\section{APPENDIXES}

TABLE 1

RELIABILITY RESULTS

\begin{tabular}{lcc}
\hline Variables & Cronbach's Alpha & N of Items \\
\hline Demographic factors & 0.518 & 14 \\
Environmental factors & 0.671 & 16 \\
Total (all variables) & 0.711 & 30 \\
\hline
\end{tabular}

Source: Field survey June-August-2015.

TABLE 2

DEMOGRAPHIC PROFILE OF THE RESPONDENTS

\begin{tabular}{l|l|l|c|c}
\hline Variables & Frequency & Percent & Mean & $\begin{array}{l}\text { Standard } \\
\text { Deviation }\end{array}$ \\
\hline Gender & & & $\mathbf{1 . 0 2}$ & $\mathbf{. 0 0 7}$ \\
Male & 392 & 98.0 & & \\
Female & 8 & 2.0 & & \\
Total & 400 & 100.0 & $\mathbf{2 . 4 7}$ & $\mathbf{. 0 4 2}$ \\
Age & & & & \\
15-25 & 46 & 11.5 & & \\
26-35 & 163 & 40.8 & & \\
36-45 & 149 & 37.2 & & \\
46-above & 42 & 10.5 & $\mathbf{0 5 5}$ \\
Total & 400 & 100.0 & & \\
Educational ability & & & & \\
Below SSC & 47 & 11.8 & & \\
SSC & 91 & 22.8 & & \\
HSC & 135 & 33.8 & & \\
Graduation & 105 & 26.2 & & $\mathbf{0 2 1}$ \\
Post-graduation & 18 & 4.5 & & \\
Diploma & 4 & 1.0 & & \\
Total & 400 & 100.0 & & \\
Marital Status & & 22.8 & & \\
Single & 91 & & & \\
\hline
\end{tabular}




\begin{tabular}{l|l|l|l|l}
\hline Variables & Frequency & Percent & Mean & $\begin{array}{l}\text { Standard } \\
\text { Deviation }\end{array}$ \\
\hline Married & 309 & 77.2 & & \\
Total & 400 & 100.0 & $\mathbf{3 . 5 3}$ & $\mathbf{. 0 7 5}$ \\
Age of Business & & & & \\
below 2 year & 14 & 3.5 & & \\
2-3 & 94 & 23.5 & & \\
4-5 & 115 & 28.8 & & \\
5-10 & 96 & 24.0 & & \\
$11-15$ & 35 & 8.8 & & \\
15-20 & 17 & 4.2 & $\mathbf{0 5 1}$ \\
20 and above & 29 & 7.2 & & \\
Total & 400 & 100.0 & & \\
Previous Employment History & & & \\
Unemployed & 100 & 25.0 & & \\
Employee & 133 & 33.2 & $\mathbf{0 . 9 5}$ \\
Entrepreneur & 102 & 25.5 & & \\
other & 65 & 16.2 & & \\
Total & 400 & 100.0 & & \\
Residential area of business & & & \\
Urban & 367 & 91.8 & & \\
Pre-urban & 32 & 8.0 & & \\
Rural & 1 & .2 & & \\
Total & 400 & 100.0 & & \\
Father's Occupation & & & & \\
Unemployed & 122 & 30.5 & & \\
Retired & 79 & 19.8 & & \\
Employee & 39 & 9.8 & & \\
Entrepreneur & 72 & 18.0 & & \\
other & 88 & 22.0 & & \\
Total & 400 & 100.0 & & \\
Mother's Occupation & & & & \\
Unemployed & 175 & 43.8 & & \\
\hline
\end{tabular}




\begin{tabular}{|c|c|c|c|c|}
\hline Variables & Frequency & Percent & Mean & $\begin{array}{l}\text { Standard } \\
\text { Deviation }\end{array}$ \\
\hline Retired & 19 & 4.8 & & \\
\hline Employee & 25 & 6.2 & & \\
\hline Entrepreneur & 14 & 3.5 & & \\
\hline other & 167 & 41.8 & & \\
\hline Total & 400 & 100.0 & & \\
\hline \multicolumn{2}{|c|}{ Position in birth order } & & 2.28 & 1.319 \\
\hline 1st born & 113 & 28.2 & & \\
\hline 2nd born & 171 & 42.8 & & \\
\hline 3rd born & 62 & 15.5 & & \\
\hline 4th born & 25 & 6.2 & & \\
\hline 5th born & 7 & 1.8 & & \\
\hline 6th born & 18 & 4.5 & & \\
\hline more than 6th born & 4 & 1.0 & & \\
\hline Total & 400 & 100.0 & & \\
\hline \multicolumn{2}{|c|}{ Spouse's Occupation } & & 3.38 & 1.760 \\
\hline Unemployed & 120 & 30.0 & & \\
\hline Retired & 18 & 4.5 & & \\
\hline Employee & 47 & 11.8 & & \\
\hline Entrepreneur & 22 & 5.5 & & \\
\hline other & 193 & 48.2 & & \\
\hline Total & 400 & 100.0 & & \\
\hline \multicolumn{2}{|c|}{ Number of employees } & & 2.46 & .055 \\
\hline No Employee & 2 & .5 & & \\
\hline $1-5$ & 30 & 7.5 & & \\
\hline $5-15$ & 248 & 62.0 & & \\
\hline $15-25$ & 68 & 17.0 & & \\
\hline $25-35$ & 26 & 6.5 & & \\
\hline $35-50$ & 8 & 2.0 & & \\
\hline 50 and above & 18 & 4.5 & & \\
\hline Total & 400 & 100.0 & & \\
\hline
\end{tabular}

Source: Field survey June-August-2015. 
TABLE 3

CORRELATION ANALYSIS

\begin{tabular}{|c|c|c|c|c|c|}
\hline \multicolumn{3}{|c|}{ Hypotheses $\left(\mathrm{H}_{1}\right) /$ Demographic Factors } & \multicolumn{3}{|c|}{ Hypotheses $\left(\mathrm{H}_{2}\right) /$ Environment Related Factors } \\
\hline Variables & $\begin{array}{c}\text { Pearson } \\
\text { Correlation }\end{array}$ & $\begin{array}{c}\mathrm{P} \\
\text { value }\end{array}$ & Variables & $\begin{array}{c}\text { Pearson } \\
\text { Correlation }\end{array}$ & $\mathrm{P}$ value \\
\hline Gender & .057 & .258 & $\begin{array}{l}\text { Sources of Fund } \\
\text { Collection }\end{array}$ & -.093 & .062 \\
\hline Age & -.056 & .268 & $\begin{array}{l}\text { Sources of Loan } \\
\text { Collection }\end{array}$ & $.172^{* *}$ & .001 \\
\hline Marital Status & .031 & .532 & Investment opportunity & .004 & .934 \\
\hline Position in birth order & $.140^{* *}$ & .005 & $\begin{array}{l}\text { Easy marketing } \\
\text { opportunity }\end{array}$ & $-.234^{* *}$ & .000 \\
\hline Residential area of business & .051 & .309 & Low legal formalities & -.082 & .102 \\
\hline Education ability & .032 & .523 & $\begin{array}{l}\text { Established national } \\
\text { business policy }\end{array}$ & $-.109^{*}$ & .029 \\
\hline Father's Occupation & -.013 & .800 & Tax facility & -.075 & .135 \\
\hline Mother's Occupation & .056 & .264 & $\begin{array}{l}\text { Availability of } \\
\text { investors }\end{array}$ & .052 & .301 \\
\hline Spouse's Occupation & .097 & .052 & $\begin{array}{l}\text { Secure Business } \\
\text { environment }\end{array}$ & $-.188^{* *}$ & .000 \\
\hline $\begin{array}{l}\text { Previous Employment } \\
\text { History }\end{array}$ & -.095 & .058 & Available customer & -.028 & .582 \\
\hline Age of Business & -.033 & .506 & $\begin{array}{l}\text { Available information } \\
\text { and communication }\end{array}$ & -.034 & .493 \\
\hline \multirow[t]{2}{*}{ Number of employees } & $.203^{* *}$ & .000 & Family background & .098 & .051 \\
\hline & & & Personal experience & .009 & .855 \\
\hline \multicolumn{3}{|c|}{ Dependent variable: Business Performance } & Family support & $.129^{*}$ & .010 \\
\hline \multicolumn{3}{|c|}{$\begin{array}{l}\text { **. Correlation is significant at the } 0.01 \text { level (2- } \\
\text { tailed). }\end{array}$} & Government support & .046 & .362 \\
\hline \multicolumn{3}{|c|}{ * Correlation is significant at the 0.05 level (2-tailed). } & $\begin{array}{l}\text { Proper use of human } \\
\text { resources }\end{array}$ & .088 & .080 \\
\hline
\end{tabular}

